\title{
Independent public healthcare unit as an entrepreneur - considerations based on the Act on Medical Activity
}

\begin{abstract}
An entrepreneur is someone that engages in a business activity on their own behalf. An entrepreneur might be a natural person, legal person and an organizational unit without legal personality, to which the legal capacity is given by a separate act. Regarding the current legislation, Supreme Court rulings and opinions contained in publications, the authors discuss the legal aspects of entrepreneur's running an autonomous public health care facility. Since the act on medical activity has become law, both the status of health care facilities and the case law concerning their status as enterprises changed.
\end{abstract}

Keywords: jurisdiction, business activity, medical activity, independent public healthcare unit, Poland.

DOI: $10.1515 /$ pjph-2015-0045

\section{INTRODUCTION}

The Act on Medical Activity (AMA) [1], entered into force with effect from 1 st of July 2011 replacing the Act of $30^{\text {th }}$ of August 1991 on healthcare institutions [2]. Since the legislator did not rule explicitly whether health care facilities engage in commercial activity, the issue of qualifying them as entrepreneurs has been puzzling researchers and literature authors for a long time. Judging by the Act on healthcare facilities, there is an overall agreement that public health care facilities are enterprises [3]. The doctrine points out that the normative approach to health care facility, which according to Art. 1 of the Act of $30^{\text {th }}$ of August 1991 on healthcare facilities is a separate organizational team of people and assets created and maintained in order to provide health care services and health promotion, is deceptively close to the definition of a company, as included in Art. 55 of the Civil Code [4] or even that it is synonymous with the concept of the entrepreneur. Also, there is an opinion that healthcare facilities do not engage in business activities [5], because their activities are covered by public funds and they are non-profit [6]. The issue of qualifying healthcare facilities as entrepreneurs also appeared in the jurisprudence. Under the Supreme Court decision signed on the $26^{\text {th }}$ of April 2002, IV CKN 1667-1600 [7], independent public health care facility are recognized as entrepreneurs. The assumption that independent public healthcare facilities should not be considered as entrepreneurs gave rise to a number of doubts. This mainly pertains to whether certain acts or regulations should be used in reference to them. Apparently, the legislator expanded the Act on Medical Activity to regulations in this regard. Practically speaking, though, these new regulations not only failed to resolve the current problem, but also introduced a number of inconsistencies and ambiguities.

\section{The Act on Medical Activity}

The Act on Medical Activity is not internally uniform in terms of classifying medical activity as a business. On the one hand, Art. 4 paragraph 1 of the Act lists the entities that may undertake therapeutic activities, stipulating that the entrepreneurs operating in all permissible for them legal forms are listed separately from the other units (Independent Public Health Care Facilities called SP ZOZ in Polish, budgetary units, foundations, associations, churches and religious associations), which may imply that SP ZOZs and budgetary units are not entrepreneurs. On the other hand, the health care services are provided on the premises of a medical entity (Art. 10 of the AMA), the organizational rules of an entity engaged in medical activities establish the organizational structure of the enterprise (Art. 24 paragraph 1 item 3 of the Act). Additionally, AMA contains references to the definition of an enterprise. For example, Art. 218 provides that whenever a separate legislation refers to health care facilities, they are regarded as healthcare entities.

\section{The Act on Freedom of Economic Activity}

The Act on Freedom of Economic Activity (AFEA) [8], determines who is an entrepreneur - within the meaning of the Art. 4 of the Act, the term 'entrepreneur' shall denote a natural person, a legal person, and a non-corporate organizational unit with legal capacity under provisions of a separate Act, conducting economic activity on its own behalf. The term 'entrepreneur' shall also denote partners in civil partnerships within the scope of their economic activities and what is the economic activity (in accordance with Art. 2 of the Act, economic activity includes profit-making activity related to manufacturing, construction, trading, providing services and prospecting, identifying and mining of minerals in deposits, as well as professional activity conducted

${ }^{1}$ Social Insurance Company (ZUS), Branch Office in Lublin, Poland

${ }^{2}$ Chair and Department of Pedodontics, Medical University of Lublin, Poland 
in an organized and continuous fashion). In Art. 4 paragraph 1 , point 1 of the AMA concerning the principles of functioning of the applicant as an entity engaged in medical activities refers to the definition of an entrepreneur contained in the AFEA.

\section{The status of the entrepreneur}

The provisions of AFEA cannot be interpreted without considering the provisions of AMA. Article 2 paragraph 1 point 4 provides a legal definition of a medical entity that is non-entrepreneur, as opposed to a therapeutic entity referred to in Article 4 paragraph 1 point 2 and 3, i.e. an independent public health care facility (point 2) and budgetary entities, including state budgetary units created and supervised by the Minister of National Defense, the Minister of Internal Affairs, the Minister of Justice or the Chief of the Internal Security Agency, which have in their organizational structure the medical procedure room/unit, medical procedure unit with a sick ward or a primary health care physician referred to in Article 55 paragraph 2a of the Act of $27^{\text {th }}$ of August 2004 on healthcare services financed from public funds [9]. This excludes qualifying the therapeutic entity acting in the form of independent public healthcare facility to the category of entrepreneurs within the meaning of the provisions of AFEA, since such a legal status is held by medical entities which are entrepreneurs within the meaning of the AFEA in all its forms provided for performing economic activities (Art. 4, paragraph 1 point 1 of the AMA). Meanwhile, independent public health care facilities have been otherwise and specifically defined in Art. 2 paragraph 1 point 4, in conjunction with Art. 4 paragraph 1 point 2 of this Act - as therapeutic entities not being entrepreneurs. It is opposed to this interpretation, that allegedly the provisions of the Act on Freedom of Economic Activity (Art. 4, paragraph. 1) or Article 431 of the Civil Code would justify the assignment to independent public health facilities of the legal status of entrepreneurs within the meaning of the AFEA, omitting the above-mentioned distinct "definitional" regulations of the AMA, which exclude such an interpretation. The fact that independent public health care units work in the corporate structure of the medical entity (Art. 23 paragraph 1 point 3 or Art. 218, paragraph 2 of the AMA) does not mean they are entrepreneurs within the meaning of the AFEA, since "constitutional "provisions of the AMA (Art. 2 paragraph 1 point 4 in conjunction with Art. 4, paragraph 1 item 2) clearly specify (define) these medical entities as non-entrepreneurs. The fact that independent public health care units can engage in commercial medical activities involving also typically "economic activities" providing chargeable private treatment services, beyond or beside services publicly funded by National Health Fund, and consequently the "jurisdictional" granting them legal personality in the sphere of civil economic turnover $[7,10]$, does not mean that in current legal status the independent public health care units are entrepreneurs within the meaning of the AFEA, because such a legal status is excluded by (negative) provisions of " constitutional" Act on Medical Activity. Furthermore, it should be noted that according to Art. 1 paragraph 2 of the Act of $20^{\text {th }}$ of August 1997 on National Court Register (KRS) [11], KRS consists of a register of entrepreneurs and from $1 \mathrm{st}$ of July 2011 - of the register of associations, other social and professional organizations, and independent public health care units. This division shows that the Independent Health Care Facility (SP ZOZ) is not entered in the register of entrepreneurs. From Art. 50 of the Act (as amended on July 1, 2011 by Art. 57 paragraph 6 of the AMA), it follows that if the entity included into the register of associations according with the Art. 49 paragraph 1, engages in economic activities, it is also a subject to the entry into the register of entrepreneurs, but with the exception of the independent public health care unit. An analysis of these provisions shows that SP ZOZs cannot be included in the register of entrepreneurs, even if they undertake an economic activity. Although the entry to the KRS "does not constitute conducting business activity, it is a proof that the entry in the register of entrepreneurs of a specific entity, will mean acknowledgment of this entity as doing business activity as if it were an entrepreneur within the meaning of the AFEA". Meanwhile, even when SPZOZ undertakes an economic activity, it does not fulfill the conditions for being entered in the register of entrepreneurs under Art. 49 of the Act on KRS.

In point 2, paragraph 1 Art. 4 of the AMA, the legislator determines that the SP ZOZ is a therapeutic entity. Also, therapeutic entities, in accordance with point 1 paragraph 1 Art. 4 of the AMA include entrepreneurs within the meaning of the Act of 2nd of July 2004 on freedom of economic activity. Thus, the legislator clearly distinguished among the entities carrying out medical activities those entrepreneurs engaged in economic activities from the SP ZOZs. Thereby the possibility of including of the therapeutic entity, acting as the SP ZOZ has been excluded from the category of the entrepreneurs within the meaning of the AFEA.

Moreover, the regulation contained in Art. 54 paragraph 1 of the AMA cannot be ignored. Under this provision, an independent public health care unit administers independently the transferred for free of charge use of property and assets of the State Treasury or local government units and own property (prepared or purchased). This provision implies, namely, that - as a rule - SP ZOZ operates, among others, using the municipal property. Also by statute, there are regulated sources from which an independent public health care unit can obtain funds.

Pursuant to Art. 55 paragraph 1 point 1 and 2 of the AMA, these resources may come from chargeable medical activities, as well as from separate activities other than chargeable therapeutic activity, if the statute provides for such activities. In view of the foregoing, it should be noted that if the legislature: firstly, clearly stipulates that an independent public health care unit is not an entrepreneur; secondly, if it introduces by statute obligation of providing this therapeutic entity with appropriate state or municipal property; thirdly, if it identifies sources of funding, it must be held that it is not an entrepreneur [10].

During attempts to clarify the status of health care facilities, there often comes to relying on outdated rulings, especially the resolution of the Supreme Court dated $11^{\text {th }}$ of May 2005 [12]. This is so unfounded that, like most of the decisions handed down in this matter, it was taken under the previous law, i.e., when the then valid law on health care facilities [2] did not specify clearly the status of independent 
public health care units. Moreover, due to the ambiguity of defining the idea of a health care facility in the case law, new legislation introduced a clear separation between the ways of understanding of assets used to conduct medical activity, understood as "wealth substrate used for providing health care services".

\section{CONCLUSIONS}

In view of the above considerations, it might be concluded that the SP ZOZ - Independent Health Care Facility does not have the status of an entrepreneur [13]. Depriving the SP ZOZ the entrepreneur status can have significant legal consequences. The AFEA mentions the entities that have the status of entrepreneurs and provides them with various guarantees in relations with public authorities, especially regarding control. For example, it predicts that as a general rule, the entrepreneur cannot have more than one business inspection at a certain moment. Also, all the inspections at the entrepreneur in one calendar year cannot last longer than 48 working days - for some entities this time is shorter. Moreover, the Act makes it possible for entrepreneurs of all kinds (micro, small and medium-size enterprises) to apply for various forms of support such as grants, training, etc. Entrepreneurs are finally legally guaranteed the opportunity to apply for release of official interpretation of tax law and social security [14]. Were the SP ZOZs deprived of their status as an entrepreneur, they would not use the specified guarantees and privileges.

\section{REFERENCES}

1. Ustawa z dnia 15 kwietnia 2011 r. o działalności leczniczej (Dz.U. 2011 $\mathrm{Nr} 112$ poz. 654 z późn. zm.).

2. Ustawa z dnia 30 sierpnia 1991 r. o zakładach opieki zdrowotnej (Dz.U. $1991 \mathrm{Nr} 91$ poz. 408 z późn. zm.).

3. Kosikowski C. Prawo działalności gospodarczej. Komentarz. Warszawa: LexisNexis; 2010. p. 15.

4. Zemke-Górecka A. Statusu samodzielnego publicznego zakładu opieki zdrowotnej i jego prywatyzacja. Warszawa: Wolters Kluwer; 2010. p. 250-2.

5. Dercz M, Rek T. Ustawa o zakładach opieki zdrowotnej. Komentarz Warszawa: Wolters Kluwer; 2010. p. 21.

6. Orłowski G. Czy szpital prowadzi działalność gospodarczą, czyli do kogo ma zastosowanie ustawa o informowaniu pracowników i przeprowadzaniu z nimi konsultacji. Monitor Prawa Pracy. 2006;8. [http://czasopisma.beck.pl/monitor-prawniczy/artykul/status-prawnysamodzielnego-publicznego-zakladu-opieki-zdrowotnej-jako-przedsiebiorcy-w-swietle-ustawy-o-dzialalnosci-leczniczej/]

7. Sąd Najwyższy w postanowieniu z dnia 26 kwietnia 2002 r., IV CKN 1667/00, Orzecznictwo Sądu Najwyższego Izba Cywilna 2003/5/65.

8. Ustawa z dnia 2 lipca 2004 r. o swobodzie działalności gospodarczej (Dz.U. $2004 \mathrm{Nr} 173$ poz. 1807 z późn. zm.).

9. Ustawa $z$ dnia 27 sierpnia 2004 r. o świadczeniach opieki zdrowotnej finansowanych ze środków publicznych (Dz. U. $2008 \mathrm{Nr}$ 164, poz. 1027 ze zm.).

10. Wyrok Naczelnego Sądu Administracyjnego z dnia 21 listopada 2014 r., II OSK 2769/14 Legalis numer 1162333.

11. Ustawa z dnia 20 sierpnia 1997 r. o Krajowym Rejestrze Sądowym (Dz.U. 1997 Nr 121 poz. 769 późn. zm.).

12. Uchwała Sądu Najwyższego z dnia 11 maja 2005 r., III CZP 11/05, Orzecznictwo Sądu Najwyższego Izba Cywilna 2006/3/48.

13. Dyląg A. Status prawny samodzielnego publicznego zakładu opieki zdrowotnej jako przedsiębiorcy w świetle ustawy o działalności leczniczej, Monitor Prawniczy 2011;17. [http://czasopisma.beck.pl/ monitor-prawniczy/artykul/status-prawny-samodzielnego-publicznegozakladu-opieki-zdrowotnej-jako-przedsiebiorcy-w-swietle-ustawy-odzialalnosci-leczniczej/]

14. Wyrok Sądu Najwyższego z dnia 22 lipca 2014 r., III UK 192/13, Legalis numer 1044945 .

\section{Corresponding author}

Jolanta Szymańska

Chair and Department of Pedodontics

Medical University of Lublin

7 Karmelicka Str.,20-081 Lublin

tel: +48 601-165-205

E-mail: szymanska.lublin@gmail.com 